\title{
FAKTOR KENYAMANAN KERJA PEKERJA RUMAH TANGGA DI PERUMNAS BETUNGAN KOTA BENGKULU
}

\author{
Oleh: \\ LINDA ASTUTI, VETHY OCTAVIANI
Prodi Ilmu Komunikasi FISIP Universitas Ratu Samban Bengkulu Utara Prodi Ilmu Komunikasi FIS Universitas Dehasen Bengkulu

\begin{abstract}
This study discusses the factors that determine the comfort of domestic workers in Bengkulu City's Betungan Housing. The aim to describe the behavior of the employer's family, wages, work activities and overview of social security to domestic workers working comfort. The research method used was a qualitative approach survey with data collection techniques of observation and interviews with informants of domestic workers residing in the RT. 12 PerumnasBetungan. The results obtained in the form of: (1) Employers in PerumnasBetungan have good behavior towards domestic workers, (2) The level of wages received by domestic workers in PerumnasBetungan is low between Rp. 500,000. up to Rp. 1,000,000, (3) Household activities carried out by domestic workers in PerumnasBetungan caring for children, cooking, washing, ironing and sweeping the house, (4) Social security received in the form of holiday bonuses, clothes and food.
\end{abstract}

Keywords: domestic workers, work comfort, worker activities.

\section{PENDAHULUAN}

Pekerjaan pekerja rumah tangga bukanlah merupakan pekerjaan ringan, mulai dari dari memasak, mencuci, mengurus rumah, mengasuh anak, berbelanja ke pasar, menyapu membersihkan pekarangan dan sebagainya. Soewondo (2009:295) mengatakan bahwa ada beberapa faktor yang mendorong wanita untuk menjadi pekerja rumah tangga yaitu:

1. Tekanan ekonomi, dengan bekerja menjadi pekerja rumah tangga memungkinkan ia dapat membantu kehidupan keluarga sehari-hari untuk dirinya sendiri.

2. Ajakan orang atau pihak kedua untuk mencari pengalaman.

3. Tidak mendapatkan kesempatan kerja di instansi pemerintahan maupun swasta, karena tidak memiliki keahlian dan pendidikan yang cukup di perlukan di instansi tersebut.

Berdasarkan pra penelitian yang dilakukan, perilaku keluarga majikan dan tingkat upah berpengaruh terhadap kondisi sosial pekerja rumah tangga, semua ini berkaitan dengan situasi pekerja rumah tangga yangsering kali berpidah-pindah kerja dengan alasan yang tidak begitu jelas. Dalam penelitian ini peneliti ingin membahas mengenai faktor yang menentukan kenyamanan pekerja rumah tangga. Akan bermanfaat agar para majikan memperlakukan pekerja rumah tangganya secara manusiawi, sehingga pekerja rumah tangga dapat bekerja dengan baik. Sehingga tujuan dari penelitian ini adalah untuk mengetahui gambaran tentang perilaku keluarga majikan, tingkat upah, aktifitas kerja dan 
gambaran jaminan sosial terhadap kenyamanan kerja pekerja rumah tangga.

\section{TINJAUAN PUSTAKA \\ Faktor Kenyaman Kerja}

Pekerja rumah tangga telah memberikan banyak jasa terhadap keluarga, terutama dalam mengasuh anakanak yang merupakan hal yang terpenting bagi suatu keluarga. Dalam pemilihan pekerja rumah tangga setiap keluarga tentu mengharapkan akan memperoleh pekerja rumah tangga yang mengetahui tugasnya dan mempunyai keterampilan yang berhubungan dengan tugasnya, keterampilan yang di harapkan majikan adalah keterampilan dalam mengurus rumah tangga dan anak majikan, Sekarningsih (1995:5) mengatakan ketampilan adalah kemampuan yang di miliki seseorang secara efektif dalam pelaksanaan suatu keinginan atau kegiatan. Pada dasarnya keterampilan hubungan dengan tugasnya karna dengan pengetahun maka ia akan dapat menjalankan atau melaksanakan keterampilannya dengan sempurna pula. Dari pendapat dapat di katakan bahwa seorang pekerja rumah tangaga memerlukan keterampilan dalam tugasnya, karena dengan adanya keterampilan yang di miliki maka seorang pekerja rumah tangga akan lebih cekatan dan cermat dalam melaksanakan tugastugasnya.

\section{Perilaku Keluarga Majikan}

Perilaku merupakan tingkah laku manusia yang dapat diamati secara langsung oleh orang atau individu bertingkah laku secara tertentu. Perilaku ada yang berbentuk positif dan berbentuk negatif. Perilaku yang berbentuk positif berarti perilaku yang tidak merugikan orang lain dan diri sendiri, sedangkan perilaku negatif berarti perilaku yang dapat merugikan orang lain maupun diri sendiri.

Menurut undang - undang ketenagakerjaan konsep majikan adalah orang yang mempekerjakan orang lain sebagai pekerja untuk melaksanakan pekerjaan dan memberikan imbalan upah. Jadi, dapat dipahami adalah tingkah laku atau tindak laku anggota keluarga majikan (ayah, ibu dan anak-anak) terhadap pekerja rumah tangga.

\section{Tingkat Upah}

Upah pada dasarnya merupakan sumber utama penghasilan seseorang, sebab itu upah harus cukup untuk memenuhi kebutuhan pekerja dan keluarganya dengan wajar. Kewajaran dapat diukur dan dinilai dengan kebutuhan pokok pekerjaan. Menurut Nitisomito (1993 : 170) : "Makin tinggi (besar) tingkat upah yang diberikan berarti semakin tercukupi pemenuhan kebutuhan hidup tenaga kerja, dengan demikian tenaga kerja akan mendapatkan ketenangan dalam menjalankan tugastugasnya sehingga semangat dan kegairahan kerjanya dapat meningkat". Dari pendapat di atas menunjukkan bahwa tingkat upah turut menentukan keberhasilan seorang tenaga kerja.

\section{Aktifitas Pekerja Rumah Tangga}

Aktifitas merupakan suatu kegiatan atau tindakan untuk menyelesaikan tugastugas. Aktifitas pekerja rumah tangga adalah kegiatan yang dilakukan oleh pekerja rumah tangga dalam menyelesaikan tugas erumah tanggaan (pekerjaan domestik)dengan imbalan gaji atau upah. Dari hasil penelitian yang pernah dilakukan di kelurahan panorama, ditunjukan bahwa tugas pekerja rumah tangga sangat luas yaitu menyangkut kelancaran suatu rumah tangga.

Pekerjaan pekerja rumah tangga meliputi memasak, menyapu, mencuci, menyetrika, bahkan mengasuh anak, serta banyak lagi tugas yang lain. Pada kondisi tertentu pekerja rumah tangga dapat merasakan dirinya tertekan karena tidak mampu melaksanakan tugas-tugas karena beban kerja yang tidak sesuai dengan kewajaran. Hal ini menunjukkan majikan keliru menilai pekerja rumah tangga sebagai mesin atau robot. Sehubungan 
dengan ketidakjelasan konsep bekerja antara pekerja rumah tangga dengan majikan itu mengakibatkan ketidak nyamanan pekerja rumah tangga.

\section{Jaminan Sosial}

Jaminan sosial merupakan salah satu cara untuk meningkatkan kesejahteraan kerja, tujuan adanya jaminan sosial adalah untuk menjamin kenyamana kerja perkerja rumah tangga dan sebagai ungkapan sosial majikan. Maka untuk itu perlu sekali bagi setiap majikan untuk memperhatikan kesejateraan bagi pekerja rumah tangga supaya kenyamanan kerja tercipta dengan baik, setiap pekerja rumah tangga berhak untuk mendapatkan jaminan sosial dari majikan di mana ia bekerja

Dalam penelitian ini peneliti ingin menbahas mengenai faktor yang menuluskan kenyamanan pekerja di rumah tangga,akan bermanfaat agar para majikan memperlakukan pekerja rumah tangganya secara manusiawi ,sehingga pekerja rumah tangga dapat bekerja dengan baik. Pemberian jaminan sosial yang diterima pekerja rumah tangga biasanya berbentuk fasilitas fisik, seperti bonus (uang selain gaji), uang transportasi jika pekerja rumah tangga pulang kedaerah asalnya, biaya ongkos berobat, pemberian pakaian sewaktu hari lebaran atau uang tunjangan hari raya dan sebagainya

\section{METODE PENELITIAN}

\section{Pendekatan Penelitian}

Tipe penelitian ini adalah penelitian yang berprespektif perempuan yaitu penelitian yang berusaha untuk mengangkat pengalaman dan pengetahuan perempuan dalam kehidupannya bermasyarakat, yang mencakup pula hubungan Gender di dalamnya, metode penelitian yang di gunakan ialah survei denga pendekatan kualitatif.

\section{Informan Penelitian}

Informan dalam penelitian ini adalah pekerja rumah tangga yang berada di RT. 12 Betungan yaitu pekerja rumah tangga sebanyak 4 orang dan majikan pekerja rumah tangga perempuan sebanyak 4 orang.

\section{Teknik Pengumpulan Data}

- Observasi

- Wawancara

\section{Teknik Analisis Data}

Penelitian ini mengunakan teknik analisis kualitatif dengan metode analisis deskriptif data karakterristik pekerja rumah tangga yang di analisis secara deskriptif untuk memperole gambaran yang menyelruh terhadap aspek-aspek yang di cari dalam penelitian ini untuk mengambil suatu kesimpulan denga tujuan utama menbuat gambaran mengenai faktor pentu kenyamanan kerja pekerja rumah tangga.

\section{HASIL DAN PEMBAHASAN}

Faktor penentu kenyamanan kerja pekerja rumah tangga di kelurahan Betungan kota Bengkulu bila dilihat dari 4 (empat) faktor hasil kajian yang di dapatkan sebagai berikut:

\section{Perilaku Keluarga Majikan}

Faktor perilaku keluarga majikan sangat menentukan untuk kenyamanan pekerja rumah tangga di tempat penelitian di lakukan, hasil yang di dapat dari keempat informan ternyata ke 4 (empat) nya mendapatkan perilaku yang baik dari keluarga majikannya baik itu majikan perempuan, laki-laki dan anak-anaknya, perilaku yang mereka dapatkan keluarga majikan tidak perna marah-marah dan menyuruh-nyuruh sambil marah-marah, pekerjaan rumah tangga yang harus di kerjakan tidak begitu berat, hanya memasak,menyapu, mencuci, mengepel lantai, membersihkan halaman dan mengasuh anak. Untuk menyetrika baju hanya mereka lakukan dua kali semingu. Sebagaimana juga di katakan oleh ibu Fina salah seorang majikan. "Saya pekerjakan mak Yopi dirumah saya sifatnya hanya sekedar membantu pekerjaan yang tidak 
bisa saya kerjakan sendiri seperti membersihkan rumah, mencuci, memasak dan menyetrikapakaian, hanya itu saja supaya betah kami sudah sepakat menganggap mak Yopi sebagai keluarga dan kepada kedua anak kami, saya mengajarkan untuk tidak menyuruhnyuruh dengan berteriak-teriak tetapi dengan kata yang baik dan sopan agar mak Yopi betah dan merasa nyaman bekerja di rumah kami karena mencari pekerja rumah tangga yang dapat di percaya zaman sekarang ini susah".

\section{Tingkat Upah}

Secara umum tingih rendahnya tingkat upah pada sarnya di tentukan berdasarkan keahlian, kecakapan, dan prestasi kerja dari tenaga kerja. Tetapi pada kenyataannya tingkat upah pekerja rumah tangga masi di bawah UMR Provinsi Bengkulu (rendah) apa bila di bandingkan pemenuhan kebutuhan yang semakin lama makin bertanbah sulit di penuhi. Sesuai dengan hasil opsevasi peneliti di mana pekerja wanita pekerja rumah tangga yang bekerja pada keluarga. Keluarga di perumnas betungan berpendapatan antaranya 500.000 sampai 1000.000 perbulan tergantung dengan banyak tidaknya perkerjaan yang di bebankan kepada mereka, walau pun upah rendah tetapi mak Yopi, mak Ical, mak Linah, dan mak Tiara semuanya menyatakan cukup menerimah upah yang di dapat walaupun harga-harga mahal tetapi mereka bekerja hanya membantu suami karena mencari nafkah utama di keluarga mereka adalah suami-auami mereka,dan juga kami tidak mengeluarkan biaya transpor untuk kerumah majikan.

\section{Aktivitas Pekerja Rumah Tangga}

Suatu gerakan kesibukan tertentu sebagai kerangka tindakan yang berkembang dan di laksanakan secara terus menerus dalam intensitas tertentu. Ibu Hannah dan ibu Lili memperkerjakan pekerja rumah tangga mengasu anak mareka yang berusia balita dan pekerja ini sudah dilakukan hampir 2 tahun oleh mak Icah dan mak Tiara kedua pekerja ini merasa beta dan nyaman bekarja dengan majikan, ibu Hannah dan ibu Lili karena kedua majikannya baik dan sangat mempercayainya mereka walau pun upah yang di dapat sebesar 500.000. begitu juga dengan mak Yopi dengan mak Linayang mendapat upah 1000.000. dan 900.000. perbulan dan merasa nyaman bekerja dengan majikan mereka , karna mendapat beban kerja yang tidak berat dan mendapat pelakuan yang baik dari majikan.

\section{Jaminan Sosial}

Kami selalu memberikan jaminan sosial kepada pekerja kami biasanya yang saya berikan berupa bonus (uang) kemudian saya berikan THR walaupun tidak sebulan gaji tapi setengah dari gaji kadang bulan puasa saya berikan sirup dan kue-kue untuk berbuka puasa demikian kata bu Hannah.

Begitu pula yang di katakan bu Lili juga sering memberikan jaminan sosial di luar gaji wajibnya oleh-oleh kalau saya dari luar kota, beras kadang saya kasi, ibu Fina juga sebagai majikansering memberi bonus-bonus di luar gaji tetap pekerja rumah tangganya. Ketika di tanyakan kapada kempat pekerja rumah tangga mereka menjawab hampir samah sering mendapatkan bonus-bonus dari masingmasing majikan mereka, hal inilah salah satu sebab mereka nyaman dan betah hanpir 2 tahun bahkan mak Yopi sudah 3 tahun bekerja pada majikan yang sama.

\section{PENUTUP}

\section{Kesimpulan}

Berdasarkan hasil dan pembahasan, maka dapat disimpulkan :

1. Majikan di Perumnas Betungan mempunyai perilaku yang baik terhadap pekerja pekerja rumah tangga

2. Tingkat upah yang di terima oleh pekerja rumah tangga di Perumnas Betungan rendah antara Rp. 500.000. sampai Rp.1000.000. 
3. Aktifitas rumah tangga yang di lakukan pekerja rumah tangga di Perumnas Betungan mengasuh anak, memasak, mencuci, setrika dan menyapu rumah.

4. Jaminan sosial yang di terima berupa bonus hari raya, pakaian dan makanan.

\section{Saran}

Tingkat upah dan jaminan sosial untuk pekerja rumah tangga di Perumnas Betungan dinaikkan minimal sesuai dengan UMR dan jaminan sosial di tambah misalkan kalau sakit di bantu biaya untuk berobat.

\section{DAFTAR PUSTAKA}

Aminollah, Arnausy. 1993. Sang Ibu Sebagai Manager Rumah Tangga. Bandung, Angkasa

Nisi Seminto, S. Alek. 1993. Manajemen Personalia (Manajemen Sumber Daya Manusia). Jakarta, Ghalia Indonesia

Sekarningsih, Reni. 1996. Pengantar Kesejahteraan Sosial, Jilid III. Bandung, Universitas Padjajaran

Soekanto, Soerjono. 1992. Kamus Sosiologi. Jakarta, CV Rajawali

Sugiono. 2012. Metode Penelitian Kombinasi. Bandung, Alfabeta 